\title{
Transformational Leadership Style and Talent Retention in Pakistani Banks: A Serial Multiple Mediation Model
}

\author{
Muhammad Masood Mir ${ }^{1 *}$, Abdullah Khan ${ }^{2}$, Qamar Abbas ${ }^{3}$ \\ *Corresponding author
}

\begin{abstract}
The objective of this research was to determine factors that mediate between transformational leadership style and retention of employees, as talent retention is an emerging issue for organizations due to workplace diversity. This study provides a guideline to the supervisors and leaders in managing their workforce. By using structural equation modeling (SEM), the result exhibited a positive impact between transformational leadership and talent retention, transformational leadership and job satisfaction, transformational leadership, and psychological ownership. The study also revealed a positive impact on job satisfaction and talent retention, psychological ownership, and talent retention. This model is an attempt to find out the further factors and measures that affect employee retention in the banking sector of Pakistan.
\end{abstract}

Keywords: transformational leadership, talent retention, psychological ownership, job satisfaction JEL Classification: J28, J54, G21

\begin{abstract}
Abstrak. Tujuan dari penelitian ini adalah untuk menentukan faktor-faktor yang memediasi antara gaya kepemimpinan transformasional dan retensi karyawan, karena retensi bakat adalah masalah yang muncul untuk organisasi karena keragaman tempat kerja. Kajian ini memberikan pedoman kepada pengawas dan pemimpin dalam mengelola tenaga kerja mereka. Dengan menggunakan pemodelan persamaan struktural (SEM), hasilnya menunjukkan dampak positif antara kepemimpinan transformasional dan retensi bakat, kepemimpinan transformasional dan kepuasan kerja, kepemimpinan transformasional, dan kepemilikan psikologis. Studi ini juga mengungkapkan dampak positif pada kepuasan kerja dan retensi bakat, kepemilikan psikologis, dan retensi bakat. Model ini merupakan upaya untuk mengetahui faktor dan langkah lebih lanjut yang mempengaruhi retensi karyawan di sektor perbankan Pakistan.
\end{abstract}

Kata Kunci: kepemimpinan transformasional, retensi bakat, kepemilikan psikologis, kepuasan kerja

\section{How to Cite:}

Mir, M. M., Khan, A., \& Abbas, Q. (2020). Transformational Leadership Style and Talent Retention in Pakistani Banks: A Serial Multiple Mediation Model. Etikonomi: Jurnal Ekonomi, 19(1), 63 - 76. https://doi.org/10.15408/etk. v19i1.11264. 


\section{Introduction}

Many people get introduced in the organizations and work for it for a long passage of time, even for the whole span of their work life. However, now employers began to face a problem called employee turnover and developed a tool to cope up with known as employee retention. Employee retention is a process of developing such an atmosphere and circumstances that keep an employee engagement with the organizations for an extended period (Wakabi, 2016). To retain employees is a severe problem in several organizations, and it affects firms disregarding because the workforce is the most valued asset for any organization, it is crucial that firms intrigue and retain their talent (Sow et al., 2016). It is essential to retain the quality workforce to maintain a loyal client and to avoid the extra cost of supplanting the employees. The leaders have to drive their firms competitively in this competing atmosphere (Wakabi, 2016). Leadership is one of the significant elements that affect employees regarding their stay and withdrawal in the organization; hence it acquires strict attention (Mwita et al., 2018). Leadership plays a vital role in promoting overall well-being at the workplace of employees, and the transformational leadership style improves the attitude and behavior of employees (Ohunakin et al., 2019).

One of such stimulants is transformational leadership. Transformational leaders direct and assist their followers to perform extraordinarily in comparison with what they thought they could perform (Bass \& Bass, 2008). These leaders positively persuade their employees and guide them to achieve their professional and individual goals (Sow et al., 2016). Besides, transformational leadership consists of idealized influence, individual consideration, inspirational motivation, and intellectual stimulation that change and transforms talent that encourages them to participate and work not for self-interest but the interest of the group as a whole.

Many service organizations are going through the dilemma of retaining talent to stay loyal to the organization. It has proved that employees do not leave organizations but leaders. (Khalid et al., 2016). In the banking sector of Pakistan, there should be more consideration given to the factors that affect talent retention, more importantly, leadership style in order to stabilize performance. Most of the organizations face high stress to retain their key talent who are most valued and tough to replace. Several types of research have done on the strategies that adequately shown results regarding talent retention (Muli et al., 2017). Organizations and leaders should focus on building positive relations with their employees to reduce the rate of employee turnover and to retain them for long (Sow et al., 2016).

Further, it stated that a transformational leadership style affects staff retention. Bushra et al. (2011) state that transformational leadership engages employees, and if this style implements, it will improve employee's commitment towards the organization. This research proposes the framework having integration of transformational leadership, psychological ownership, job satisfaction, and talent retention.

In past years banking sectors have suffered from a high rate of turnovers (Muli et al., 2017). Therefore this paper design to explore the integrated relationship between stated elements with talent retention in the banking sector. A transformational leader knows clearly 
about the organizational goals and commitments, and he effectively communicates the objectives and the ways to achieve them to employees (Izidor \& Iheriohanma, 2015). The role of transformational leaders is to boost the morale and confidence of their employees towards the organization (Bass, 1999). Transformational leadership comprised of idealized influence, individualized consideration, inspirational motivation, and intellectual stimulation (Sow et al., 2016). Bass (1999) uses the term charisma for idealized influence. Inspiration comes from leaders, but it cannot state that it is single-dimensional. Transformational leaders inspire through their skills of communication and the way they direct their team towards achieving organizational goals. Followers are encouraged to work above their self-interests, and they perform more than expectations due to the leader's inspirational and motivational support that follows examples. These leaders do not encourage competitiveness but promote team spirit, self-confidence and a positive, friendly environment (Assaf et al., 2016)

Intellectual stimulation defines as an act of a leader that promotes creativity and innovation along with problem-solving and critical thinking. Transformational leaders encourage followers to come up with innovations and different ideas to do a task. Intellectual stimulation works as a process in which individuals identify problems, rectify situations according to that, do critical analysis through innovative ideas, and set goals. According to Assaf et al. (2016), individualized consideration focuses on each employee separately. The leader concerns about the follower's matters and issues related to work and personal problems too. Leaders figure out and prove solutions, support, and assistance to the individual employee that boosts their confidence and belief in their leader. Transformational leaders care about their followers and know their needs and expectations and try to fulfill them.

Transformational leadership is linked with psychological ownership positively as employee's work commitment is influenced and boost up through transforming leader. When the transformational leadership style exercise, it will increase the level of ownership and employee engagement. Furthermore, practices of transformational leadership also remove negative relationship factors and influence employees to indulge in work with full dedication (Ghafoor et al., 2011).

Talent retention focuses on the identification of reasons due to which skilled employees leave the organization along with seeking measures that improve employee sustainability (Wakabi, 2016). Organizations have to ensure that their employees remain with them for the longest possible passage of time. Talent retention is a process that involves strategies and methods that play an important role in keeping employees attached to the organization for a more extended period, even though retaining talent is a tough task for organizations nowadays (Mwita et al., 2018). Job satisfaction is an essential factor and is prominently affected by the job environment and leader behavior. Usually, job satisfaction is a condition that appears when employees get a feeling of comfort and gratification regarding their job and environment (Belias \& Koustelios, 2014).

People who feel ownership of the object are more likely to perform for that; this sense of ownership defines the level of the individual's motivation towards the organization. Psychological ownership builds a relationship between the employees, and the employer's 
sense of ownership builds agreement between the organization and the individual. After owning the organization, an employee shows more passion for the organization and the organization's common goal (Ghafoor et al., 2011). Many employees have stated that their decision to stay and leaving organizations depends upon the level of their satisfaction. Many factors affect the job satisfaction of employees, and cannot be specified generally.

Furthermore, more the employees are satisfied more they would be their chances to retain (Motlou et al., 2016). Job satisfaction and talent retention are some of the most critical issues for organizations. Talent retention is considered as one of the primary measures while evaluating a firm's effectiveness because employees are the primary source of productivity (Flores et al., 2011). The decision of retention base on the work conditions provided in the workplace and support that satisfies an employee and retains him/her for a more extended period (Valentine et al., 2015).

The part of transformational leadership is always crucial at the workplace, not only because organizations want to satisfy the employees but also to retain them, so this should examine with organizational factors (Ohunakin et al., 2019). Psychological ownership is a new concept that needs to be further investigated with other human resource variables in different sectors (Imam et al., 2018). The research model of the study is tested for the first time with serial multiple mediation effect in the banking sectors of Pakistan by using several factors such as transformational leadership style on talent retention with the mediation effect of psychological ownership and job satisfaction. This fact is noteworthy to mention that the concept of transformational leadership is not very new. However, the application of this concept in Pakistan is gradually taking height, so the endeavor of this research will be very significant for all the stakeholders to see this relationship with a unique mediation effect.

The purpose of the research is to provide the guidelines to human resource specialists in managing personnel in banking sectors, as talent retention is an emerging issue. Employees tend to leave the organization due to multiple opportunities and job diversity. On the other hand, the workplace environment and the behavior of supervisors also impact the turnover intentions. The research will contribute to determining such phenomena and factors that influence talent retention and will improvement of employee performance in banking sectors. The main objectives of the research are to find out the impact of transformational leadership through its characteristics on talent retention, the direct impact of idealized influence, individualized consideration, inspirational motivation, and intellectual stimulation, on talent retention. Furthermore, this research is also going to examine the indirect impact of the variables such as idealized influence, individualized consideration, inspirational motivation, and intellectual stimulation to talent retention through psychological ownership and job satisfaction.

\section{Methods}

The sampling population of the research was the employees of the banking sector of Pakistan. After data cleaning, the sample became 155 and was ready to test. Somehow the similar sample size and the respondent used in the studies of (Anwar \& Miftahuddin 2016; 
Assaf et al., 2016; Mwita et al., 2018). The survey was based on constructed questionnaires for observation to collect the responses of sample respondents. The data has been collected randomly by using a questionnaire that included two sections in which. The first section included the demographics of the respondents, and the other section includes the closedended questions related to the constructs as the attributes of transformational leadership styles were used, such as idealized influence, individualized consideration, inspirational motivation, and intellectual stimulation.

To test and interpret the data, this research using structural equation modeling (SEM). SEM technique is the finest to achieve the appropriate results. Additionally, some of the indicators delete due to the lack of factor loadings and the validity issues like PO4, TR1, TR2, TR4, IS2, and IS4 after that the validity and reliability were fit to test. The indicators should delete those who are not making the benchmark values of factor loadings of 0.70 can harm the validity and the reliability of the data. In the case, the indicators showing the fewer factor loadings should delete, as they are not fit to load the latent variable of that particular constructs (Haier et al., 2014).

Figure 1 shows the theoretical framework of the study showing the relation of the leadership styles with two mediators one are job satisfaction, and the other is psychological ownership. Moreover, job satisfaction is showing serial mediation as the psychological ownership also impacts it, and then both are going towards talent retention, as talent retention is dependent variable here.

Figure 1. The Framework of the study

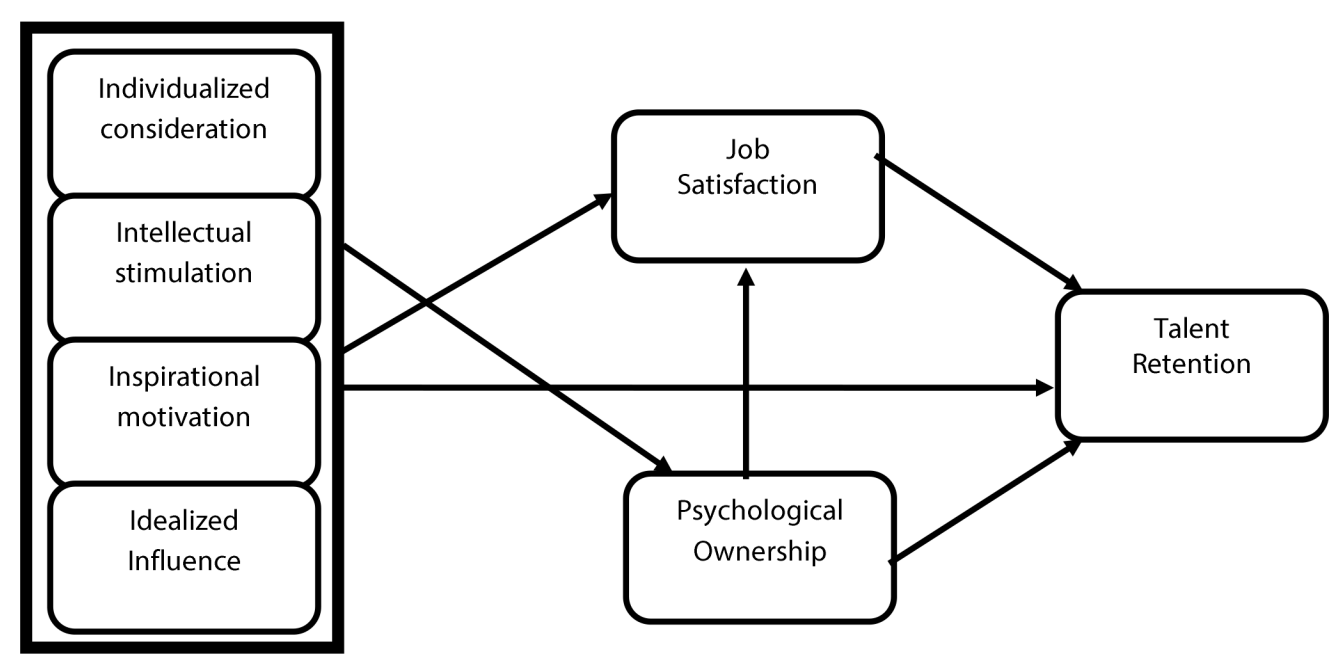

\section{Result and Discussion}

Table 1 shows the demographics of the respondents of this research. The result shows that 116 respondents were males, and 39 were females selected randomly, which make $74.8 \%$ of males and $25.2 \%$ females. Furthermore, the percentage of education column exhibited that higher percentage includes 53.5\% for bachelor's level employees and 34.2\% for Master's level from, there were also some Ph.D., and a high level of employees include. Table 1 also 
elaborating respondents' age brackets. $50.3 \%$ of respondents were between 20-30 ages, $38.1 \%$ were in $30-40$, and $18 \%$ were above 40 . Whereas, the experience shows that most of the employees, $29.7 \%$ having experience of 2 to 4 years, and $24.5 \%$, were showing the experience of the 4 to 6 years.

Table 1. Demographics

\begin{tabular}{llllll}
\hline Gender & Frequency & Percentage & Age & Frequency & Percentage \\
\hline Male & 116 & 74.8 & $20-30$ & 78 & 50.3 \\
Female & 39 & 25.2 & $30-40$ & 59 & 38.1 \\
Total & $\mathbf{1 5 5}$ & $\mathbf{1 0 0 . 0}$ & $40-50$ & 16 & 10.3 \\
& & & 50 -above & 2 & 1.3 \\
Education & & & Total & 155 & $\mathbf{1 0 0 . 0}$ \\
Matriculation & 4 & 2.6 & Experience & & \\
Intermediate & 9 & 5.8 & 0-2yrs & 36 & 23.2 \\
Bachelors & 83 & 53.5 & 2-4yrs & 46 & 29.7 \\
Masters & 53 & 34.2 & 4-6yrs & 38 & 24.5 \\
PHD \& above & 6 & 3.9 & 6-8yrs & 16 & 10.3 \\
Total & $\mathbf{1 5 5}$ & $\mathbf{1 0 0 . 0}$ & 8-above & 19 & 12.3 \\
& & & Total & $\mathbf{1 5 5}$ & $\mathbf{1 0 0 . 0}$ \\
\hline
\end{tabular}

Table 2 presents the values of idealized influence, individualized consideration, inspirational motivation, job satisfaction within the range of 0.70 , and 0.99 and is acceptable with the reference. Furthermore, the AVE shows convergent validity that evaluates the gradation to which two measures of the same concept are correlated (Haier et al., 2014). Hence it can be said that the data that use for the testing purpose possess the internal consistency and the accuracy for further testing.

Table 2. Construct Reliability and Validity

\begin{tabular}{lcccc}
\hline & $\begin{array}{c}\text { Cronbach's } \\
\text { Alpha }\end{array}$ & rho_A & $\begin{array}{c}\text { Composite } \\
\text { Reliability }\end{array}$ & $\begin{array}{c}\text { Average Variance } \\
\text { Extracted (AVE) }\end{array}$ \\
\hline Idealized Influence - & 0.757 & 0.760 & 0.846 & 0.578 \\
Individualized Consideration & 0.745 & 0.750 & 0.839 & 0.567 \\
Inspirational Motivation & 0.767 & 0.769 & 0.852 & 0.590 \\
Intellectual Stimulation & 0.704 & 0.705 & 0.871 & 0.771 \\
Job Satisfaction & 0.813 & 0.815 & 0.878 & 0.643 \\
Psychological Ownership & 0.726 & 0.766 & 0.828 & 0.552 \\
Talent Retention & 0.734 & 0.733 & 0.881 & 0.787 \\
\hline
\end{tabular}

Discriminant validity test is of utmost importance in research. It involves latent variables with the use of numerous indicators for construct demonstrating. Discriminant validity evaluates and explains the extent to which variables and indicators differ from each other (Haier et al., 2014). Fornell- Larcker criterion is another test for validity; it compares the 
average variance extracted (AVE's) square root with the latent construct's correlation (Haier et al., 2014). Furthermore, the variance must be better explained by its latent construct. Thus, each construct AVE's square root value should be higher than other correlated latent constructs values (Fornell \& Larcker, 1981). All the diagonal values in Table 3 should be higher than the off-diagonal values. It shows that all the diagonal values are not less than any off-diagonal values that consequently show discriminant validity.

Table 3. Fornell- Larcker Criterion

\begin{tabular}{|c|c|c|c|c|c|c|c|}
\hline & $\begin{array}{l}\text { Idealized } \\
\text { Influence }\end{array}$ & $\begin{array}{l}\text { Individualized } \\
\text { Consideration }\end{array}$ & $\begin{array}{l}\text { Inspirational } \\
\text { Motivation }\end{array}$ & $\begin{array}{l}\text { Intellectual } \\
\text { Stimulation }\end{array}$ & $\begin{array}{c}\text { Job } \\
\text { Satisfaction }\end{array}$ & $\begin{array}{l}\text { Psychological } \\
\text { Ownership }\end{array}$ & $\begin{array}{c}\text { Talent } \\
\text { Retention }\end{array}$ \\
\hline Idealized Influence_ & 0.76 & & & & & & \\
\hline Individualized Consideration & 0.599 & 0.753 & & & & & \\
\hline Inspirational Motivation & 0.739 & 0.642 & 0.768 & & & & \\
\hline Intellectual Stimulation & 0.527 & 0.47 & 0.502 & 0.878 & & & \\
\hline Job Satisfaction & 0.669 & 0.629 & 0.587 & 0.486 & 0.802 & & \\
\hline Psychological Ownership & 0.559 & 0.607 & 0.546 & 0.452 & 0.6 & 0.743 & \\
\hline Talent Retention & 0.538 & 0.527 & 0.505 & 0.304 & 0.622 & 0.503 & 0.887 \\
\hline
\end{tabular}

Table 4. Cross-loadings

\begin{tabular}{|c|c|c|c|c|c|c|c|}
\hline & $\begin{array}{l}\text { Idealized } \\
\text { Influence }\end{array}$ & $\begin{array}{l}\text { Individualized } \\
\text { Consideration }\end{array}$ & $\begin{array}{l}\text { Inspirational } \\
\text { Motivation }\end{array}$ & $\begin{array}{l}\text { Intellectual } \\
\text { Stimulation }\end{array}$ & $\begin{array}{c}\text { Job } \\
\text { Satisfaction }\end{array}$ & $\begin{array}{l}\text { Psychological } \\
\text { Ownership }\end{array}$ & $\begin{array}{c}\text { Talent } \\
\text { Retention }\end{array}$ \\
\hline II 1 & 0.725 & 0.402 & 0.461 & 0.393 & 0.423 & 0.416 & 0.405 \\
\hline II 2 & 0.778 & 0.469 & 0.581 & 0.438 & 0.583 & 0.481 & 0.393 \\
\hline II 3 & 0.776 & 0.441 & 0.615 & 0.369 & 0.509 & 0.384 & 0.428 \\
\hline II 4 & 0.762 & 0.504 & 0.584 & 0.4 & 0.508 & 0.416 & 0.413 \\
\hline IC 1 & 0.551 & 0.81 & 0.568 & 0.327 & 0.53 & 0.464 & 0.476 \\
\hline IC 2 & 0.42 & 0.753 & 0.43 & 0.353 & 0.497 & 0.394 & 0.379 \\
\hline IC 3 & 0.366 & 0.717 & 0.404 & 0.434 & 0.415 & 0.447 & 0.288 \\
\hline IC 5 & 0.447 & 0.728 & 0.514 & 0.319 & 0.443 & 0.519 & 0.424 \\
\hline IM 2 & 0.556 & 0.484 & 0.796 & 0.36 & 0.427 & 0.419 & 0.475 \\
\hline IM 3 & 0.602 & 0.544 & 0.797 & 0.422 & 0.469 & 0.447 & 0.351 \\
\hline IM 4 & 0.581 & 0.472 & 0.754 & 0.504 & 0.431 & 0.463 & 0.324 \\
\hline IM1 & 0.53 & 0.472 & 0.723 & 0.257 & 0.477 & 0.349 & 0.396 \\
\hline IS 1 & 0.502 & 0.417 & 0.452 & 0.885 & 0.434 & 0.419 & 0.262 \\
\hline IS 3 & 0.422 & 0.408 & 0.43 & 0.871 & 0.419 & 0.374 & 0.271 \\
\hline JS 1 & 0.576 & 0.472 & 0.441 & 0.34 & 0.828 & 0.451 & 0.509 \\
\hline JS 2 & 0.521 & 0.538 & 0.493 & 0.402 & 0.785 & 0.494 & 0.485 \\
\hline JS 3 & 0.548 & 0.534 & 0.449 & 0.429 & 0.872 & 0.553 & 0.519 \\
\hline JS 4 & 0.499 & 0.471 & 0.502 & 0.388 & 0.715 & 0.42 & 0.479 \\
\hline PO 1 & 0.429 & 0.506 & 0.478 & 0.393 & 0.474 & 0.813 & 0.403 \\
\hline PO 2 & 0.493 & 0.545 & 0.478 & 0.379 & 0.512 & 0.837 & 0.469 \\
\hline $\mathrm{PO} 3$ & 0.407 & 0.423 & 0.39 & 0.327 & 0.428 & 0.729 & 0.336 \\
\hline PO 5 & 0.314 & 0.282 & 0.225 & 0.214 & 0.356 & 0.562 & 0.249 \\
\hline TR3 & 0.491 & 0.529 & 0.444 & 0.296 & 0.578 & 0.44 & 0.897 \\
\hline TR5 & 0.462 & 0.401 & 0.453 & 0.241 & 0.524 & 0.454 & 0.877 \\
\hline
\end{tabular}


Table 5. Heterotrait-Monotrait Ratio (HTMT)

\begin{tabular}{|c|c|c|c|c|c|c|c|}
\hline & $\begin{array}{l}\text { Idealized } \\
\text { Influence }\end{array}$ & $\begin{array}{l}\text { Individualized } \\
\text { Consideration }\end{array}$ & $\begin{array}{l}\text { Inspirational } \\
\text { Motivation }\end{array}$ & $\begin{array}{l}\text { Intellectual } \\
\text { Stimulation }\end{array}$ & $\begin{array}{c}\text { Job } \\
\text { Satisfaction }\end{array}$ & $\begin{array}{c}\text { Psychological } \\
\text { Ownership }\end{array}$ & $\begin{array}{c}\text { Talent } \\
\text { Retention }\end{array}$ \\
\hline \multicolumn{8}{|l|}{ Idealized Influence } \\
\hline Individualized Consideration & 0.788 & & & & & & \\
\hline Inspirational Motivation & 0.967 & 0.842 & & & & & \\
\hline Intellectual Stimulation & 0.719 & 0.657 & 0.684 & & & & \\
\hline Job Satisfaction & 0.849 & 0.806 & 0.747 & 0.643 & & & \\
\hline Psychological Ownership & 0.745 & 0.804 & 0.71 & 0.618 & 0.777 & & \\
\hline Talent Retention & 0.724 & 0.702 & 0.674 & 0.422 & 0.807 & 0.676 & \\
\hline
\end{tabular}

Another measure to assess the discriminant validity is cross-loading, which states that the factor loadings of indicators of assigned constructs must have values higher than loadings of other constructs and should be not less than 0.70 (Fornell \& Larcker, 1981; Haier et al., 2014). Table 4 shows the indicator's factor loadings with assigned constructs are higher than other loadings and are also $>0.70$; therefore, all lie on acceptable discriminant validity according to the given reference.

According to Sidek et al. (2017), the Hetero trait -mono trait ratio of correlation if it shows values near to 1 indicated low discriminant validity and the values must not exceed the threshold value such as 0.85 ; otherwise, it will also indicate the low discriminant validity. In Table 5, all the latent variables are showing $(0.788,0.842,0.684,0.643,0.777$, and 0.676) values that are below 0.85 hence they all have acceptable discriminant validity.

Table 6. R Square Matrix

\begin{tabular}{lcc}
\hline & R Square & R Square Adjusted \\
\hline Job Satisfaction & 0.563 & 0.548 \\
Psychological Ownership & 0.445 & 0.43 \\
Talent Retention & 0.449 & 0.426 \\
\hline
\end{tabular}

Table 6 presents the value of $r$-square 0.563 is showing that transformational leadership and it is four attributes that are idealized influence, intellectual stimulation, individualized consideration, and inspirational motivation are explaining $56.3 \%$ variance in job satisfaction. Furthermore, the value of a 0.445 is indicating that a transformational leadership style is explaining a $44.5 \%$ variance in psychological ownership. Moreover, transformational leadership with psychological ownership and job satisfaction is explaining a $44.9 \%$ variance in talent retention.

Table 7 is showing the values of relationships such as direct and indirect relationships of constructs. It influences is showing full mediation with psychological ownership and job satisfaction with the values of idealized influence and psychological ownership, and idealized influence with job satisfaction. On the other hand, idealized influence is showing insignificant relation with talent retention directly as its $\mathrm{t}$ value 1.074 and $\mathrm{p}$-value 0.283 are $\mathrm{t}$ 
$<2$ and $\mathrm{p}>0.05$ standardized values. Hence it is suggested that idealized influence leadership style, if provided, it will increase the psychological ownership of the employees as well as job satisfaction, and they both will enhance the talent retention in the organization.

Similarly, individualized consideration is showing full mediation with psychological ownership, and job satisfaction with the values of individualized consideration and psychological ownership, and that of individualized consideration and job satisfaction. Therefore, the researcher is rejecting the null hypothesis, and in the case of individualized consideration and talent retention, their direct relationship is not significant.

Table 7. Bootstrapping

\begin{tabular}{|c|c|c|c|c|c|}
\hline & $\begin{array}{l}\text { Original } \\
\text { Sample }\end{array}$ & $\begin{array}{l}\text { Sample } \\
\text { Mean }\end{array}$ & $\begin{array}{l}\text { Standard } \\
\text { Deviation }\end{array}$ & T-Stat & P Values \\
\hline Idealized Influence -> Job Satisfaction & 0.351 & 0.356 & 0.075 & 4.699 & 0.000 \\
\hline Idealized Influence -> Psychological Ownership & 0.205 & 0.207 & 0.096 & 2.122 & 0.034 \\
\hline Idealized Influence -> Talent Retention & 0.125 & 0.121 & 0.117 & 1.074 & 0.283 \\
\hline Individualized Consideration -> Job Satisfaction & 0.241 & 0.237 & 0.110 & 2.185 & 0.029 \\
\hline $\begin{array}{l}\text { Individualized Consideration -> Psychological } \\
\text { Ownership }\end{array}$ & 0.362 & 0.352 & 0.121 & 2.987 & 0.003 \\
\hline Individualized Consideration-> Talent Retention & 0.129 & 0.129 & 0.101 & 1.276 & 0.203 \\
\hline Inspirational Motivation -> Job Satisfaction & 0.014 & 0.017 & 0.080 & 0.169 & 0.866 \\
\hline $\begin{array}{l}\text { Inspirational Motivation } \quad->\text { Psychological } \\
\text { Ownership }\end{array}$ & 0.099 & 0.106 & 0.115 & 0.859 & 0.390 \\
\hline Inspirational Motivation -> Talent Retention & 0.095 & 0.093 & 0.104 & 0.908 & 0.364 \\
\hline Intellectual Simulation -> Job Satisfaction & 0.085 & 0.085 & 0.072 & 1.189 & 0.235 \\
\hline $\begin{array}{l}\text { Intellectual Simulation } \rightarrow \text { Psychological } \\
\text { Ownership }\end{array}$ & 0.123 & 0.128 & 0.087 & 1.415 & 0.158 \\
\hline Intellectual Simulation -> Talent Retention & -0.112 & -0.115 & 0.082 & 1.362 & 0.174 \\
\hline Job Satisfaction -> Talent Retention & 0.381 & 0.390 & 0.100 & 3.803 & 0.000 \\
\hline Psychological Ownership -> Job Satisfaction & 0.212 & 0.211 & 0.095 & 2.228 & 0.026 \\
\hline Psychological Ownership -> Talent Retention & 0.124 & 0.123 & 0.093 & 1.334 & 0.183 \\
\hline
\end{tabular}

On the other hand, the relationships of inspirational motivations with mediation job satisfaction and psychological ownership is showing no significant relation. Likewise, the relationship between intellectual stimulation and mediation psychological ownership and job satisfaction shows no mediations towards talent retention and is also not significant. Furthermore, job satisfaction and talent retention are showing a significant relation. Also, psychological ownership and talent retention are showing no significant relationship. Moreover, Psychological ownership and job satisfaction is showing a significant relationship. Hence it is proved when the idealized influence, individualized consideration styles provide in the banking sectors, and then it enhances the psychological ownership as well as job 
satisfaction, then it increases the retention of the talent in the organization. Moreover, job satisfaction mediates the relation between idealized influences, individualized consideration, and psychological ownership and then enhances the talent retention in the organization.

Figure 2 shows the SEM model and the result of the Bootstrapping. The values written on the arrows going from one latent variable to others are showing the t-values and clearly showing the acceptance, and the rejection of the variables discussed before. Figure 2 shows that idealized influence and the individualized consideration are showing full mediation towards talent retention. Besides, the other two are insignificant within the banking sectors of Pakistan. Whereas, the psychological ownership mediating between job satisfaction and talent retention.

Figure 2. Bootstrapping

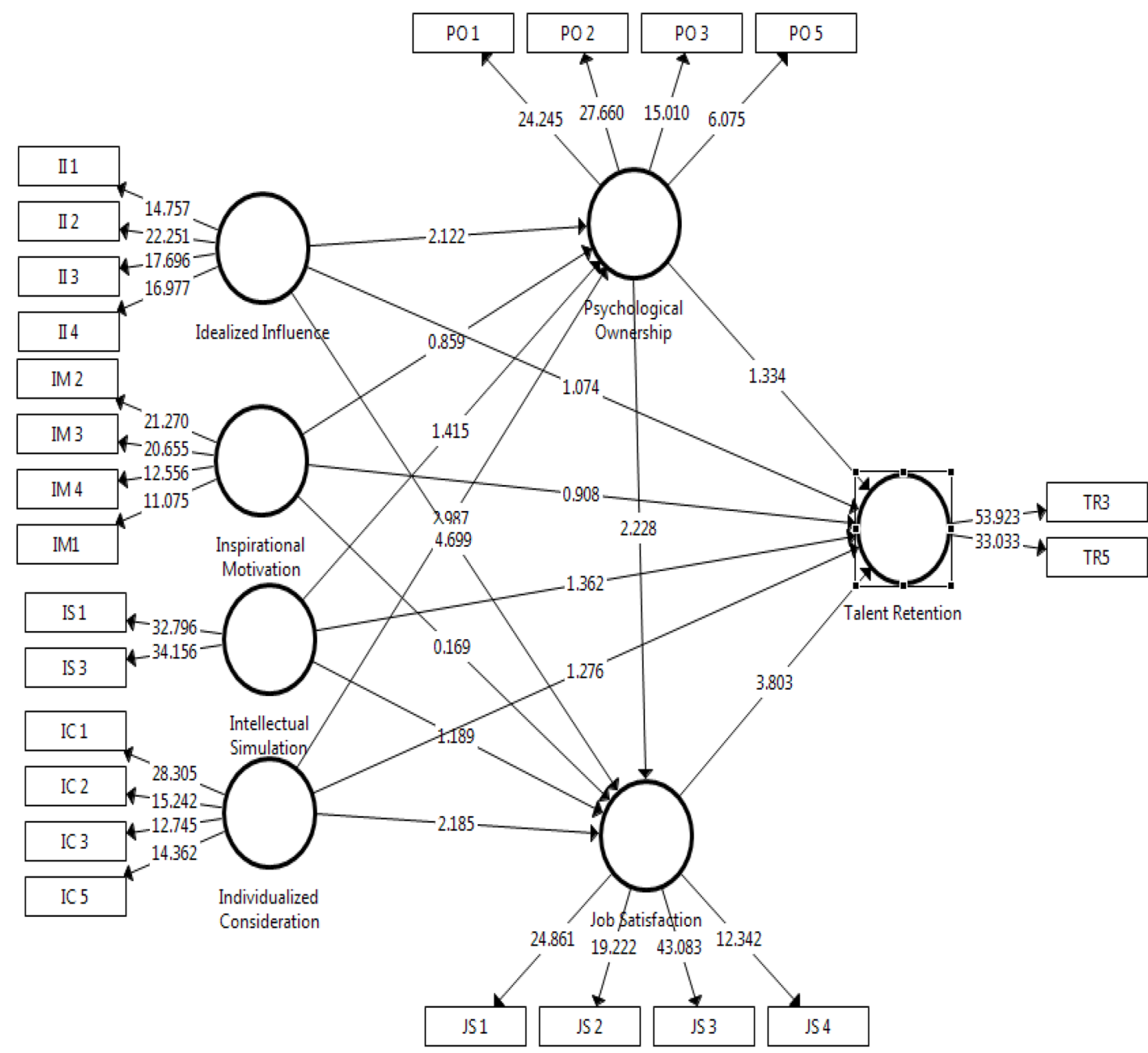

The overall analysis of the study is showing that the attribute of the transformational leadership style has an impact on talent retention through the mediation of psychological ownership and job satisfaction. As it is showing that idealized influence and individualized consideration are showing a significant relationship with psychological ownership and job 
satisfaction, hence it suggests that providing the idealized influence and individualized consideration leadership style to the employees will enhance their emotional attachment towards the organization. Then the employee feels satisfaction towards the job. The influence of boss matters if the case is for retaining the talent and treatment in an individualized manner is according to their temperament they feel very attached and associated with the organization and feel satisfied that eventually leads to retaining the best talent as the economic downturns affected the entire talent management process of many industries in Pakistan.

However, the other two styles of transformational leadership, like intellectual stimulation and inspirational motivation, are not making any impact with psychological ownership and job satisfaction on talent retention. This study focuses on understanding which of the transformational leadership style influences the most and by direct or indirect mediation, and the previous studies showed the relationship with only transformational leadership style as the primary variable. Furthermore, the results are consistent with the study conducted by Anwar \& Miftahuddin (2016) suggested that the transformational leadership style is a factor that increases the job satisfaction of the employees, and they feel motivated towards their job. In another study conducted by Joo \& Lim (2013), they found the transformational leadership style plays a vital role in enhancing the career satisfaction of the employees.

The empirical results are also consistent with the study of Cho et al. (2015) highlighted that a good leadership style with the employees, makes a positive relationship with the sense of ownership. After getting a leadership style focused on idealizing them, considered them the part of the team and helping them to increase their capabilities, leads to enhance the sense of ownership of the employees. Like the current study, the transformational leadership style is not making any direct relation with the talent retention falsifies the previous study conducted by Muli et al. (2017), highlighted that the competent leadership styles enhance the retention. However, in this study, it is falsified and proved that leadership style not directly associated with retention but with the mediation of psychological ownership and job satisfaction.

Moreover, the results suggest that there is a relationship between psychological ownership and job satisfaction. Hence it suggests that if the psychological ownership of the employees enhanced, it would increase the satisfaction level of the employees. If an employee creates a sense of ownership, they feel satisfied with the job. The results are consistent with Joo $\& \operatorname{Lim}$ (2013) emphasized that a transformational leadership style enhances job satisfaction. Additionally, it is also that the transformation leadership style enhances the job satisfaction of the employees, which is fully mediated by psychological ownership. Psychological ownership is insignificant with talent retention, but it is making the relation with the mediation of job satisfaction. Hence if the psychological ownership enhances then, it will enhance job satisfaction, and then the talent will be retained in the organization. The results are falsifying the study of Olckers \& Plessis (2012); Olzer et al. (2008) both have highlighted that psychological ownership has a positive relationship with the retention of the talent.

The current study has proved that by providing psychological ownership, employee feels satisfaction, and then it enhances the retention in the organization. This study also found 
out that the job satisfaction after getting the psychological ownership that is enhanced by the leadership style would ultimately enhance the retention of the talent in the organization. The results are consistent with Jugurnath et al. (2016) that also find a positive relationship between employee job satisfaction and retention. Khalid et al. (2016) highlighted that job satisfaction mediates the relationship between the leadership style and the retention of the employees.

\section{Conclusion}

According to the findings of this research leader's idealized influence through instilling pride in his/her followers. It is going beyond self-interest, portraying a sense of power and boosting the confidence of follower's impacts clearly on follower's intention to stay in the bank for a more extended period. Similarly, it also found when a leader spends time coaching teaching employees, promoting their self-development and strength, listening to their concerns, and treating team members individually, it will impact their behavior to retain with the bank longer. The mediation hypothesis indicated that when employee's morale gets high, and they get access to promotions and opportunities with an honest and trustworthy workplace environment, the intent to remain in the workplace for a longer time.

Moreover, inspirational motivation by the leader through helping in finding meaning in work and providing an image about what can do does not impact the bank's talent to remain with the bank for long. Further, it also found that leader's encouragement to nontraditional thinking and the suggestions for new ways of re-examining critical assumptions does not make them stay with the bank and work for it for the long passage of time. The research also indicated that talent's only emotional attachment and psychological ownership in decisions, actions, and carrying out work does not encourage talent retention. Hence, it can conclude as transformational leadership with its two traits, idealized influence and individualized consideration, impacts talent retention through the two mediations of psychological ownership and job satisfaction.

This study recommends that retaining talented employee's organizations should work for their well-being and satisfaction. Manager can enhance the sense of psychological ownership by using a transformational leadership style that will ultimately increase the loyalty level among employees. It has suggested that future researchers can go to other cities, and for multiple cities at a time, another direction for future researches is the moderating effect of gender of the leader can also test. Furthermore, service sectors other than the banking sector can also choose to analyze the impacts of transformational leadership on talent retention through mediation in other sectors.

\section{References}

Anwar, P. M., \& Miftahuddin. (2016). The Effect of Transformational Leadership and Job Satisfaction on Employee Performance. Universal Journal of Management, 4(4), 189195. https://doi.org/10.13189/ujm.2016.040404

Assaf, N., Qudah, M. A., \& Bashayreh, A. (2016). Does Transformational Leadership Style 
effect on Employee Commitment in the Aviation Industry. International Journal of Business and Management, 11(12), 163-176.

Bass, B. M. (1999). Two Decades of Research and Development in Transformational Leadership. European Journal of Work and Organizational Psychology, 8(1), 9-32

Bass, B. M., \& Bass, R. (2008). The Bass Handbook of Leadership: Theory, Research, and Managerial Applications (4 ed.). NewYork: Free Press.

Belias, D., \& Koustelios, A. (2014). Transformational Leadership and Job Satisfaction in the Banking Sector. International Review of Management and Marketing, 4(3), 187-200.

Bushra, F., Usman, A., \& Naveed, A. (2011). Effect of Transformational Leadership on Employees' Job Satisfaction and Commitment. International Journal of Business and Social Science, 2(18), 261-267.

Cummings GG, MacGregor T, Davey M, Lee H, Wong CA, Lo E, Muise M, Stafford E. (2010, March). Leadership styles and outcome patterns for the nursing workforce and work environment: a systematic review. International Journal of Nursing Studies, 47(3), 363-385.

Cho, H. P., Woocheol, K., \& Ji, H. S. (2015). The Impact of Ethical Leadership on Employees' In-Role Performance: The Mediating Effect of Employees' Psychological Ownership. Human Resource Development Quarterly, 26(4), 385-408.

Flores, C., Boyle, A. R., \& Melichar, D. Y. (2011). Assisted Living Administration and Management: Effective Practices and Model Programs in Elder Care (1st ed.). NewYork: Springer Publishing Company.

Fornell, C., \& Larcker, D. F. (1981). Evaluating Structural Equation Models with Unobservable Variables and Measurement Error. Journal of Marketing Research, 18(1), 39-50.

Ghafoor, A., Qureshi, T. M., Khan, M. A., \& Hijazi, S. T. (2011). Transformational Leadership, Employee Engagement, and Performance: Mediating Effect of Psychological Ownership. African Journal of Business Management, 5(17), 7391-7403.

Hair, J. F., Black, W. C., Babin, B. J., \& Anderson, R. E. (2010). Multivariate Data Analysis (Seventh ed.). (D. Kindersley, Ed.) London: Pearson Education Limited.

Haier, J., Hult, G., Ringle, C., \& Sarstedt, M. (2014). A Primer on Partial Least Squares Structural Equation Modeling. (PLS-SEM). Los Angeles: SAGE Publications, Incorporated.

Imam, T., Ali, H., \& Soo, H. S. (2018). Mediating Role of Psychological Capital in Talent Retention amongst Pharmaceutical Employees of Pakistan: A Quantitative Study. International Journal of Academic Research in Business and Social Sciences, 8(6), 389-405.

Izidor, N., \& Iheriohanma, E.B.J, (2015). The Nexus Between Leadership Styles and Employee Retention and Performance. European Scientific Journal, 11(13), 185-209.

Joo, B. K., \& Lim, T. (2013). Transformational Leadership and Career Satisfaction: The Mediating Role of Psychological Empowerment. Journal of Leadership \& Organizational Studies, 1(2), 1-10. https://doi.org/10.1177/1548051813484359 
Jugurnath, B., Bhewa, C., \& Ramen, M. (2016). Employee Satisfaction and Retention in Health Services: Empirical Evidence at the ENT Hospital Mauritius. In Proceedings of the Fifth Asia-Pacific Conference on Global Business, Economics, Finance, pp. 1-22. Mauritius.

Khalid, N., Pahi, M. H., \& Ahmed, O. (2016). Losing Your Best Talent: Can Leadership Retain Employees? the dilemma of the banking sector of Hyderabad Pakistan. International Review of Management and Marketing, 6(3), 608-616.

Motlou, G. R., Singh, S., \& Karodia, M. A. (2016). An Evaluation of The Impact of Job Satisfaction on Employee Retention at Lonmin Rowland Shaft North West Province. Arabian Journal of Business and Management Review, 5(10), 15-49.

Muli, B., Ngui, T. k., \& Mohamed, R. (2017). Factors Determining Employee Retention in the Banking Sector. Journal of Education \& Entrepreneurship, 4(10), 1-23.

Mwita, K. M., Mwakasangula, E., \& Tefurukwa, O. (2018). The Influence of Leadership on Employee Retention. International Journal of Human Resource Studies, 8(2), 274-283.

Ohunakin, F., Adeniji, A. A., Oludayo, O. A., Osibanjo, A. O., \& Oduyoye, O. O. (2019). Employees' Retention in Nigeria's Hospitality Industry: The Role of Transformational Leadership Style and Job Satisfaction. Journal of Human Resources in Hospitality \& Tourism, 18(3), 1-29.

Olckers, C., \& Plessis, D. Y. (2012). The Role of Psychological Ownership in Retaining Talent: a Systematic Literature Review. Journal of Human Resource Management, 10(2), $1-18$.

Olzer, H., Yilmaz, A., \& Olzer, A. (2008). Psychological Ownership: an Empirical Study on Its Antecedents and Impacts Upon Organizational Behavior. Problems and Perspectives in Management, 6(3), 38-47.

Fisher R.A. (1992) Statistical Methods for Research Workers. In: Kotz S., Johnson N.L. (eds) Breakthroughs in Statistics. Springer Series in Statistics (Perspectives in Statistics). Springer, New York, N

Sidek, M. H., Sami, W., \& Hamid, M. R. (2017). Discriminant Validity Assessment: Use of Fornell \& Larcker Criterion Versus HTMT Criterion. Journal of Physics: Conference Series, 890, 1-5. https://doi.org/10.1088/1742-6596/890/1/012163.

Sow, M., Damon, A., \& Osuoha, R. (2016). The Relationship between Transformational Leadership and Employee Retention among Healthcare Professionals in the United States. Business and Economic Research, 6(2), 235-254.

Valentine, R. S., Jackson, H. J., \& Mathis, L. R. (2015). Human Resource Management: Essential Perspective (7th edition ed.). California: South-Western College Pub

W, H. M., Nico W, Y. V., Barbara, W., \& Kai, S. (2011). Transformational-transactional leadership styles and followers' regulatory focus: Fit reduces followers' turnover intentions. Journal of Personnel Psychology, 10(4), 182-186.

Wakabi, B. M. (2016). Leadership Style and Staff Retention in Organizations. International Journal of Science and Research, 5(1), 412-416. 